\title{
Obesity in patients with end-stage heart failure
}

\author{
Bogumiła Król'ㄹ, Aleksandra Oprzędkiewicz², Wioletta Szczurek², Bożena Szyguła-Jurkiewicz³ \\ ${ }^{1}$ Department of Cardiosurgery, Transplantology, Vascular and Endovascular Surgery, Office of Transplant \\ Coordination, Silesian Centre for Heart Diseases, Zabrze, Poland \\ ${ }^{2}$ Student Scientific Society, $3^{\text {rd }}$ Department of Cardiology, School of Medicine with Division of Dentistry \\ in Zabrze, Medical University of Silesia in Katowice, Poland \\ ${ }_{3}^{3} 3^{\text {rd }}$ Department of Cardiology, School of Medicine with Division of Dentistry in Zabrze, Medical University of Silesia \\ in Katowice, Poland
}

Kardiochirurgia i Torakochirurgia Polska 2018; 15 (3): 176-179

\begin{abstract}
Obesity poses an increasing problem in patients with endstage heart failure (HF). The most commonly used indicator of obesity is body mass index. The value of this parameter is widely taken into consideration when selecting the best way of treatment for patients with advanced HF. The aim of this paper is to outline the recent knowledge about obesity in the abovementioned group of patients.
\end{abstract}

Key words: obesity, end-stage heart failure.

\section{Introduction}

Obesity is an increasing social and health problem in developing countries. The most commonly used indicator to evaluate obesity is the body mass index (BMI) calculated as weight in kilograms divided by height in meters squared $\left(\mathrm{kg} / \mathrm{m}^{2}\right)$. Obesity is defined as a BMI of $30 \mathrm{~kg} / \mathrm{m}^{2}$ or more. In general, population obesity is considered a major risk factor of type 2 diabetes and cardiovascular diseases [1-7]. The BMI is also an important parameter taken into consideration during the selection of treatment in end-stage heart failure (HF). As generally acknowledged, treatment options in this group of patients include optimal medical treatment, mechanical circulatory support (MCS), and heart transplantation (HT) [8]. Pre-transplant BMI > $30 \mathrm{~kg} / \mathrm{m}^{2}$ and percent ideal body weight $(\mathrm{PIBW})>140 \%$ are associated with a poor outcome after the surgery. Therefore, the ISHLT (International Society of Heart and Lung Transplantation) guidelines for the care of $\mathrm{HT}$ candidates recommend weight loss to achieve a BMI of $<30 \mathrm{~kg} / \mathrm{m}^{2}$ or percent $\mathrm{BMI}$ of $<140 \%$ of target before listing for HT [8]. It should be noted that finding an appropriate donor for an obese recipient often proves difficult. The guidelines of the ISHLT recommend that the heart from a donor weighing $<70 \%$ of the recipient's body weight should not be accepted unless the organ

\section{Streszczenie}

Otyłość stanowi coraz większy problem zdrowotny i społeczny u chorych z zaawansowaną niewydolnością serca (NS). Najczęściej stosowanym parametrem oceniającym stan odżywienia chorego jest wskaźnik masy ciała. Wartość tego parametru jest brana pod uwagę przy wyborze strategii postępowania u chorych z zaawansowaną NS. Celem niniejszej pracy jest przedstawienie aktualnego stanu wiedzy na temat otyłości u pacjentów z zaawansowaną NS.

Słowa kluczowe: otyłość, zaawansowana niewydolność serca.

is from a male donor weighing $>70 \mathrm{~kg}$ [8]. In their clinical practice, some HT centers use a more conservative $20 \%$ instead of the $30 \%$ weight mismatch recommended by the ISHLT Guidelines, and patients with a BMI $>30 \mathrm{~kg} / \mathrm{m}^{2}$ may wait longer due to the inability to identify an appropriately matched donor and are significantly less likely to receive a HT than patients of normal weight [9]. A chance for obese patients with end-stage HF is offered by MCS. Some researchers have found no association between a higher BMI and increased mortality after left ventricular assist device (LVAD) implantation [10, 11]. Furthermore, obese patients achieve a significant weight loss after device implantation compared to the medically treated group [12]. In such situations, an LVAD is really a bridge to HT.

\section{Obesity and the cardiac muscle}

Obesity is a great load for a human heart. It is widely known that the morphology and the function of the obese patient's heart are impaired. The cardiac output is increased, which leads to hypertrophy of the left ventricle and anterograde diastolic and systolic dysfunction of both ventricles. Moreover, overweight is strongly associated with hypertension, diabetes mellitus and sleep apnea, all of which contribute to the deteriorating function of the 
cardiovascular system [1, 2, 4, 7]. The progressive worsening of heart dysfunction is the reason why the blood flow is reduced, while muscles are more insufficiently provided with oxygen and nutrients. That is only one of several mechanisms explaining the decline in effort capacity connected with HF. The impact of the products of anaerobic transformations on the ergoreceptors is also debated. It is believed that they boost receptors in muscles, which - via sensory nerves and the central nervous system - activates the sympathetic nervous system and the respiratory center, and reduces tension of the baroreflexes and the vagus nerve. This compensatory process is very useful in healthy people, but in patients with HF it intensifies destructive changes in the cardiac muscle [13]. All this results in the reduction of physical effort undertaken by the patient and a further weight gain. The above consideration shows that obesity can be both the reason and the result of the escalation of HF. Body mass reduction results in a decrease in left ventricular mass and, even more importantly, leads to a decrease in blood pressure and the level of neurohormones associated with obesity [13]. Notwithstanding, multiple authors have shown that obese patients have a low mortality risk - a phenomenon known as the "obesity paradox" [14-16].

\section{Obesity paradox}

Early studies about a better prognosis and lower mortality rate in obese patients with HF were published in the 1990s [15], but an increased interest in the topic of obesity and HF was observed after 2002, when Gruberg et al. noticed that obese patients after percutaneous heart interventions had a lower one-year mortality rate than the non-obese ones [16]. Since then, a lot of studies have been performed with the intention of explaining this phenomenon. At first, it seemed that lean patients have some underlying diseases which exert some influence on a poorer prognosis [16]. Over the last years, attempts have been made to discover a pathophysiological basis of the obesity paradox [17]. Obese patients are known to have a greater metabolic reserve, lower vascular resistance, and lower activity of the renin-angiotensin-aldosterone system than lean ones $[16,18]$. These factors may have an influence on better outcomes in the selected group of obese patient, who are considered "metabolically healthy" [16]. It was also proved that the obesity paradox could not be observed in patients with HF and the metabolic syndrome. Insulin resistance in this group of patients is associated with activation of the sympathetic nerves and the renin-angiotensin-aldosterone system, and leads to worse outcomes [19]. While the population of patients developing both $\mathrm{HF}$ and the metabolic syndrome is growing, the obesity paradox seems to be in decline nowadays.

The results of a prospective study by Piepoli et al. showed that a factor more important than BMI was exercise tolerance, indicated by peak oxygen consumption. When patients were grouped by this factor, BMI had no influence on survival [20].

\section{Body mass index and time on the waiting list}

One of the most important stages in the process of qualification for a HT is appropriate donor-recipient matching. As we mentioned earlier, research showed that appropriate fitting, including the same gender and a similar BMI, is even more important than a correct BMI per se. What is alarming is that the proportion of patients with $\mathrm{BMI} \geq 30 \mathrm{~kg} / \mathrm{m}^{2}$ listed for a HT has significantly increased in the last 20 years [21]. In most cases, obesity is connected with many other illnesses, such as metabolic syndrome, diabetes, hypertension, etc. As a result, it is harder to find an obese donor whose heart meets transplantation requirements. Zieliński et al. reported a significant decrease in the chances of receiving a heart when the patient weighs over $80 \mathrm{~kg}$, and these chances are even smaller in the group with the weight greater than $110 \mathrm{~kg}$ [22]. Weiss et al. demonstrated that patients with $\mathrm{BMI} \geq 30 \mathrm{~kg} / \mathrm{m}^{2}$ spend twice as much time on the waiting list and are $35 \%$ less likely to receive a transplantation than patients with correct weight [9].

\section{Obesity and left ventricular assist devices}

The LVADs can be used in end-stage HF as a destination therapy or as a bridge to transplantation. There have been many studies concerned with the impact of LVADs on body weight in obesity patients [12, 23-25]. Dhesi et al. assessed changes in total body weight, morbidity and mortality in obese HF patients after implantation of a pulsatile LVAD. The authors of this study showed that an LVAD can be used successfully as a bridge to weight loss and subsequent HT [12]. Clerkin et al. found that weight loss in obese patients as a result of continuous-flow LVAD implantation is possible, though uncommon [23]. It seems that the effect of weight reduction is dependent on the device type [24, 25]. Yanagida et al. found that pulsatile devices are associated with greater weight loss than nonpulsatile continuous flow devices [24]. This observation may be explained by the inherent differences in weight and size of the devices; however, the exact mechanistic differences remain unclear.

The total weight, shape and physical location of the LVAD seem to play a key role in reducing caloric intake. The devices are positioned in the abdominal cavity, leading to compression of the gastric antrum, which consequently contributes to gastric fullness, early feeling of satiety and prolonged gastric emptying [12, 23-25]. In addition, improvements in exercise capacity after LVAD implantation also lead to increased caloric expenditure as a result of increased physical activity undertaken by the patient [26] Considering the above, devices can cause both increased caloric expenditure and decreased caloric intake so that it is possible to lose weight.

Regardless of the LVAD's direct influence on the patient's weight, it appears that this procedure can be used together with a sleeve gastrectomy to afford HT eligibility [27]. In order to expedite their weight loss, establishment of a weight loss program for obese LVAD recipients may also be necessary. 
It should also be emphasized that the patients with a greater BMI have lower probability of finding the right donor, and therefore weight loss after LVAD implantation can improve their chance for HT. With all the benefits brought by the implementation of LVAD for obese patients awaiting HT, the side effects of this therapy, such as infections, bleedings, and thrombosis, should be taken into consideration. Patients who are particularly exposed to these complications include those with BMI greater than $35[28,29]$.

\section{Obesity after heart transplantation}

Obesity after $\mathrm{HT}$ is becoming an increasing problem. Not only is the group of obese patients undergoing this kind of operation becoming more numerous, but also a considerable number of heart recipients observed after the surgery experience an increase in weight, especially 1 year after HT [30]. Grady et al. reported that the BMIs of $79 \%$ of them increased after $\mathrm{HT}$, with an excessively high BMI before the surgery reported as the strongest risk factor [31]. Particularly vulnerable to post-operation weight gain are black and young patients with a non-ischemic etiology of HF, as well as patients whose immunosuppressive treatment does not include mycophenolate mofetil [31].

Gaining weight after HT is strongly associated with the development of many complications within both the shortand long-term observation period [32-34]. It was revealed that obesity is a risk factor for primary graft failure [32], diabetes mellitus [33, 34], and cardiac allograft vasculopathy [35]. In addition, obesity is associated with a higher rate of 1-year mortality after the surgery [32, 33]. A worsened prognosis in this group of patients could be connected with more frequent complications in the perioperative period $[36,37]$. The probability of the above complications after $\mathrm{HT}$ in obese patients may be reduced by regular physical activity and losing weight. Regular exercise training after HT improves exercise capacity and peak oxygen uptake, positively influences the endothelium through increased nitric oxide production, and by reduction of inflammation also contributes to slower development of cardiac allograft vasculopathy [38-40].

Considering the increased risk of perioperative complications, the development of comorbidities and poorer prognosis after HT in obesity patients, physicians should encourage their patients with high BMI to lose weight both while waiting for and after the heart transplant. It is necessary to introduce wide-ranging prevention programs aimed at promoting a healthy lifestyle and maintain proper body weight in the long-term follow-up after HT.

\section{Conclusions}

Obesity is a growing problem in the population of advanced HF patients who are qualified for advanced forms of therapy such as HT and LVAD. The presence of obesity in a candidate for $\mathrm{HT}$ is associated with reduced probability of finding the right donor, longer waiting time on the list and increased risk of postoperative complications. The LVAD implantation may offer a chance for obese patients who are not eligible for HT or cannot find the right donor. However, a decision to select this kind of therapeutic procedure should be carefully considered because of possible complications after device implantation. Considering the risks posed by obesity and its increasing prevalence in the advanced HF population, development of safe weight loss programs for obese ventricular assist device and HT recipients is necessary.

\section{Disclosure}

The authors report no conflict of interest.

\section{References}

1. Alpert MA, Omran J, Mehra A, Ardhanari S. Impact of obesity and weight loss on cardiac performance and morphology in adults. Prog Cardiovasc Dis 2014; 56: 391-400.

2. Martín-Timón I, Sevillano-Collantes C, Segura-Galindo A, Del Cańizo-Gómez FJ. Type 2 diabetes and cardiovascular disease: have all risk factors the same strength? World J Diabetes 2014; 5: 444-470.

3. Jonsson S, Hedblad B, Engstrom G, Nilsson P, Berglund G, Janzon L. Influence of obesity on cardiovascular risk. Twenty-three-year follow-up of 22,025 men from an urban Swedish population. Int J Obes Relat Metab Disord 2002; 26: 1046-1053.

4. Mikhail N, Golub MS, Tuck ML. Obesity and hypertension. Prog Cardiovasc Dis 1999; 42: 39-58.

5. Howard BV, Ruotolo G, Robbins DC. Obesity and dyslipidemia. Endocrinol Metab lin North Am 2003; 32: 855-867.

6. Kenchaiah S, Evans JC, Levy D, Wilson PW, Benjamin EJ, Larson MG, Kannel WB, Vasan RS. Obesity and the risk of heart failure. N Engl J Med 2002; 347: 305-313.

7. Jubber AS. Respiratory complications of obesity. Int J Clin Pract 2004; 58: 573-580.

8. Mehra MR, Canter CE, Hannan MM, Semigran MJ, Uber PA, Baran DA, Danziger-Isakov L, Kirklin JK, Kirk R, MD, Kushwaha SS, Lund LH, Potena L, Ross HJ, Taylor DO, Verschuuren EAM, Zuckermann A; the International Society for Heart Lung Transplantation (ISHLT), Infectious Diseases, Pediatric and Heart Failure and Transplantation Councils. The 2016 International Society for Heart Lung Transplantation listing criteria for heart transplantation: a 10-year update. J Heart Lung Transplant 2016; 35: 1-23.

9. Weiss ES, Allen JG, Russel SD, Shah AS, Conte JV. Impact of recipient body mass index on organ allocation and mortality in orthotopic heart transplantation. J Heart Lung Transplant 2009; 28: 1150-1157.

10. Butler J, Howser R, Portner PM, Pierson RN. Body mass index and outcomes after left ventricular assist device placement. Ann Thorac Surg 2005; 79: 66-73.

11. Mano A, Fujita K, Uenomachi K, Kazama K, Katabuchi M, Wada K, Terakawa $\mathrm{N}$, Arai K, Hori Y, Hashimoto S, Nakatani T, Kitamura S. Body mass index is a useful predictor of prognosis after left ventricular assist system implantation. J Heart Lung Transplant 2009; 28: 428-433.

12. Dhesi P, Simsir SA, Dansthvar D, Rafique A, Phan A, Schwarz ER. Left ventricular assist device as a bridge to weight loss prior to transplantation in obese patients with advanced heart failure. Ann Transplant 2011; 16: 5-13.

13. Poirier P, Giles TD, Bray GA, Hong Y, Stern JS, Pi-Sunyer FX, Eckel RH. Obesity and cardiovascular disease: pathophysiology, evaluation, and effect of weight loss: an update of the 1997 American Heart Association Scientific Statement on Obesity and Heart Disease from the Obesity Committee of the Council on Nutrition, Physical Activity, and Metabolism. Circulation 2006; 113: 898-918.

14. Curtis JP, Selter JG, Wang Y, Rathore SS, Jovin IS, Jadbabaie F, Kosiborod M, Portnay EL, Sokol SI, Bader F, Krumholz HM. The obesity paradox: body mass index and outcomes in patients with heart failure. Arch Intern Med 2005; 165: 55-61.

15. Ellis SG, Elliot J, Horrigan M, Raymond RE, Howell G. Low-normal or excessive body mass index: newly identified and powerful risk factors for death and other complications with percutaneous coronary intervention. Am J Cardiol 1996; 78: 642-646.

16. Gruberg L, Weissman NJ, Waksman R, Fuchs S, Deible R, Pinnow EE, Ahmed LM, Kent KM, Pichard AD, Suddath WO, Satler LF, Lindsay J Jr. The im- 
pact of obesity on the short-term and long-term outcomes after percutaneous coronary intervention: the obesity paradox? J Am Coll Cardiol 2002; 39: 578-584.

17. Ades PA, Savage PD. The obesity paradox: perception vs knowledge. Mayo Clin Proc 2010; 85: 112-114.

18. Hainer V, Aldhoon-Hainerová I. Obesity paradox does exist. Diabetes Care 2013; 36: S276-S281.

19. Narumi T, Watanabe T, Kadowaki S, Otaki Y, Honda Y, Nishiyama S, Takahashi $\mathrm{H}$, Arimoto T, Shishido T, Miyamoto T, Kubota I. The obesity paradox is not observed in chronic heart failure patients with metabolic syndrome. EXCLI J 2014; 13: 516-525.

20. Piepoli MF, Corrà U, Veglia F, Bonomi A, Salvioni E, Cattadori G, Metra M, Lombardi C, Sinagra G, Limongelli G, Raimondo R, Re F, Magrì D, Belardinelli R, Parati G, Minà C, Scardovi AB, Guazzi M, Cicoira M, Scrutinio D, Di Lenarda A, Bussotti M, Frigerio M, Correale M, Villani GQ, Paolillo S, Pas sino C, Agostoni P. Exercise tolerance can explain the obesity paradox in patients with systolic heart failure: data from the MECKI Score Research Group. Eur J Heart Fail 2016; 18: 545-553.

21. Amarelli C, Buonocore M, Romano G, Maiello C, De Santo LS. Nutritiona issues in heart transplant candidates and recipients. Front Biosci (Elite Ed) 2012; 4: 662-668.

22. Zieliński T, Sobieszczańska-Małek M, Browarek A, Piotrowska M, Zakliczyński M, Przybyłowski P, Roguski K, Sadowski J, Zembala M, Korewicki J. The influence of recipient's body weight on the probability to obtain a heart transplant - POLKARD HF Registry. Transplant Proc 2009; 41: 3166-3170.

23. Clerkin KJ, Naka Y, Mancini DM, Colombo PC, Topkara VK. The impact of obesity on patients bridged to transplantation with continuous-flow left ventricular assist devices. JACC Heart Fail 2016; 4: 761-768.

24. Yanagida R, Czer LS, Mirocha J, Rafiei M, Esmailian F, Moriguchi J, Kobash igawa JA, Trento A. Left ventricular assist device in patients with body mass index greater than 30 as bridge to weight loss and heart transplant candidacy. Transplant Proc 2014; 46: 3575-3579.

25. Thompson K, Dhesi P, Nguyen D, Czer L, Moriguchi J, Schwarz E. Evaluation of the HeartMate $\mathrm{IIM}^{\mathrm{TM}}$ left ventricular assist device in obese heart failure patients: effects on weight loss. Ann Transplant 2011; 16: 63-67.

26. de Jonge $N$, Kirkels $H$, Lahpor JR, Klöpping C, Hulzebos EJ, de la Rivière AB, Robles de Medina EO. Exercise performance in patients with end-stage heart failure after implantation of a left ventricular assist device and after heart transplantation: an outlook for permanent assisting? J Am Coll Cardiol 2001; 37: 1794-1799.

27. Greene J, Tran T, Shope T. Sleeve gastrectomy and left ventricular assist device for heart transplant. JSLS 2017; 21: 22-26.

28. Raymond AL, Kfoury AG, Bishop CJ, Davis ES, Goebel KM, Stoker S, Selzman $\mathrm{CH}$, Clayson SE, Smith H, Cowley CG, Alharethi R, Budge D, Reid BB. Obesity and left ventricular assist device driveline exit site infection. ASAIO J 2010; 56: 57-60.

29. Han JJ, Sooppan R, Johnson AP, Chen CW, Gaffey AC, Phillips EC, Howard J, Rame JE, Acker MA, Atluri P. Higher body mass index increases risk of HeartMate II pump thrombosis but does not adversely affect long-term survival. Circ J 2017; 81: 213-219.

30. Beckmann S, Nikolic N, Denhaerynck K, Binet I, Koller M, Boely E, De Geest S. Evolution of body weight parameters up to 3 years after solid organ transplantation: the prospective Swiss Transplant Cohort Study. Clin Transplant 2017; 31: e12896.

31. Grady KL, Naftel D, Pamboukian SV, Frazier OH, Hauptman P, Herre J, Eisen H, Smart F, Bourge R. Post-operative obesity and cachexia are risk factors for morbidity and mortality after heart transplant: multi-institutional study of post-operative weight change. J Heart Lung Transplant 2005; 24: 1424-1430.

32. Guisado Rasco A, Sobrino Márquez JM, Nevado Portero J, Romero Rodríguez N, Ballesteros Prada S, Lage Gallé E, Martínez Martínez A. Impact of overweight on survival and primary graft failure after heart transplantation. Transplant Proc 2010; 42: 3178-3180.

33. Kahn J, Rehak P, Schweiger M, Wasler A, Wascher T, Tscheliessnigg KH, Müller $\mathrm{H}$. The impact of overweight on the development of diabetes after heart transplantation. Clin Transplant 2006; 20: 62-66.

34. Garlicki M. Post-transplant diabetes mellitus (PTDM) in heart recipients. Ann Transplant 2005; 10: 51-53.

35. Ramzy D, Rao V, Brahm J, Miriuka S, Delgado D, Ross HJ. Cardiac allograft vasculopathy: a review. Can J Surg 2005; 48: 319-327.

36. De JongA, Molinari N, Pouzeratte $Y$, Verzili D, Chanques G, Jung B, Futier E, Perrigault PF, Colson P, Capdevila X, Jaber S. Difficult intubation in obese patients: incidence, risk factors, and complications in the operating theatre and in intensive care units. Br J Anaesth 2015; 114: 297-306.

37. Grady KL, White-Williams C, Naftel D, Costanzo MR, Pitts D, Rayburn B, VanBakel A, Jaski B, Bourge R, Kirklin J. Are preoperative obesity and cachexia risk factors for post heart transplant morbidity and mortality: a multi-institutional study of preoperative weight-height indices. Cardiac Transplant Research Database (CTRD) Group. J Heart Lung Transplant 1999; 18: 750-763.

38. Yardley M, Gullestad L, Bendz B, Bjørkelund E, Rolid K, Arora S, Nytrøen K. Long-term effects of high-intensity interval training in heart transplant recipients: a 5-year follow-up study of a randomized controlled trial. Clin Transplant 2017. DOI: 10.1111/ctr.12868.

39. Hermann TS, Dall CH, Christensen SB, Goetze JP, Prescott E, Gustafsson F Effect of high intensity exercise on peak oxygen uptake and endothelial function in long-term heart transplant recipients. Am J Transplant 2011; 11: 536-541

40. Nytrøen K, Gullestad L. Exercise after heart transplantation: an overview. World J Transplant 2013; 3: 78-90. 